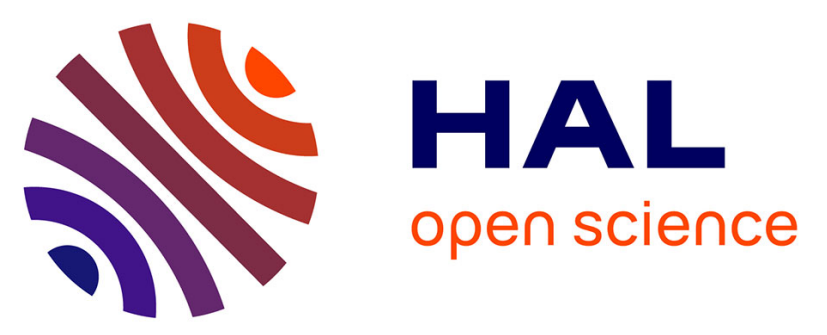

\title{
Flow electrolysis on high surface electrode for biodegradability enhancement of sulfamethazine solutions
}

I. Saidi, Isabelle Soutrel, Florence Fourcade, Abdeltif Amrane, Didier Floner, Nizar Bellakhal, Florence Geneste

\section{To cite this version:}

I. Saidi, Isabelle Soutrel, Florence Fourcade, Abdeltif Amrane, Didier Floner, et al.. Flow electrolysis on high surface electrode for biodegradability enhancement of sulfamethazine solutions. Journal of electroanalytical chemistry and interfacial electrochemistry, 2013, 707, pp.122-128. 10.1016/j.jelechem.2013.09.006 . hal-00914406

\author{
HAL Id: hal-00914406 \\ https://hal.science/hal-00914406
}

Submitted on 5 Dec 2013

HAL is a multi-disciplinary open access archive for the deposit and dissemination of scientific research documents, whether they are published or not. The documents may come from teaching and research institutions in France or abroad, or from public or private research centers.
L'archive ouverte pluridisciplinaire HAL, est destinée au dépôt et à la diffusion de documents scientifiques de niveau recherche, publiés ou non, émanant des établissements d'enseignement et de recherche français ou étrangers, des laboratoires publics ou privés. 
Flow electrolysis on high surface electrode for biodegradability enhancement of sulfamethazine solutions

\author{
I. Saidi ${ }^{1,3,4}$, I. Soutrel ${ }^{2,4}$, F. Fourcade ${ }^{1,2,4}$, A. Amrane* 1, 2, 4, D. Floner ${ }^{1,4}$, N. Bellakhal ${ }^{3}$, F. \\ Geneste* 1,4
}

1) Institut des Sciences Chimiques de Rennes, Université de Rennes 1, UMR-CNRS 6226, Campus de Beaulieu, 35042 Rennes Cedex, France.

2) Institut des Sciences Chimiques de Rennes, Ecole Nationale Supérieure de Chimie de Rennes, UMR-CNRS 6226, Avenue du Général Leclerc, CS 50837, 35042 Renne Cedex 7, France.

3) Laboratoire de recherche de Catalyse d'Electrochimie de Nanomatériaux et leurs applications et de didactique CENAD, Institut National des Sciences Appliquées et de Technologie (INSAT), B.P.Nº76, 1080 Tunis Cedex, Tunisie.

4) Université Européenne de Bretagne, 35000 Rennes, France

\begin{abstract}
:
The main objective of this study was to examine the feasibility of coupling an electrochemical process with a biological treatment for the degradation of sulfamethazine, a biorecalcitrant antibiotic. The electrochemical behavior of sulfamethazine was examined by cyclic voltammetry, showing an electroactivity in oxidation. The pre-treatment was carried out using an electrochemical flow cell involving a graphite felt electrode of high specific area. After a single pass through the cell, the analysis of the electrolyzed solution showed a promising trend in view of the proposed combined process, namely a high degradation of the target compound (more than 90\%) while the mineralization level remained low (it did not exceed $20 \%$ ). The optimization of the operating conditions, viz. flow rate and applied potential, allowed to improve the biodegradability of sulfamethazine solutions. Indeed, under optimal conditions, the biodegradability based on the $\mathrm{BOD}_{5}$ on $\mathrm{COD}$ ratio measurement was improved from 0.08 to 0.58 , namely above the threshold limit value $(0.4)$.
\end{abstract}

Key words: Sulfamethazine, Electrochemical pre-treatment, Biodegradability, Combined process, Graphite felt, Flow cell 


\section{Introduction}

Pharmaceuticals have been widely used as human and veterinary medicinal compounds. Due to their intensive consumption worldwide, their occurrence in aquatic environment (typically in the range of ng to $\mu \mathrm{g} / \mathrm{L}$ ) has been observed [1-4]. The assessment of the impact to human health from environmental exposure has been the subject of many investigations [5-9]. Even if the amount of pharmaceuticals in aquatic environment is low, indirect effects such as chronic exposure, mixture effects and development of antibiotic resistant bacteria may constitute a risk for aquatic and terrestrial organisms. Thus, several efforts are being made to find out ways of inactivating or eliminating this class of substances in surface or wastewater.

Pharmaceuticals can be removed by physical techniques, such as membrane technologies [1011] or adsorption processes [12-13]. For example, techniques involving activated carbon [14], reverse osmosis [15], coagulation [16] and flocculation [17] have been applied. However, these techniques are not destructive and the pollutant is only transferred to another phase [1819]. Consequently, expensive regeneration and post treatment processes are required.

Oxidation processes have also proven their efficiency in the treatment of toxic organic pollutants and biorecalcitrant compounds. Among them, Advanced Oxidation Processes (AOP) have been widely used, since they involve hydroxyl radicals $\left(\mathrm{OH}^{\circ}\right)$, which are very reactive and can attack most of the organic molecules [20-21]. Degradation of pharmaceuticals have been reported by oxidation treatments such as ozonation processes [22] and by AOP processes, such as anodic oxidation on Boron Doped Diamond electrode [20, 23 24], electro-Fenton [20, 23], photo-Fenton [25] and photocatalysis [26]. Although complete mineralization of the pollutant can be achieved by this method, they are expensive and not selective.

Even if biological treatment processes are economical, they can be ineffective for the degradation of recalcitrant compounds such as pharmaceuticals [27-28]. The use of integrated processes, such as the coupling of AOP and biological treatment is therefore an interesting alternative to degrade biorecalcitrant compounds at reduced operating costs [18, 19, 27-30]. The pre-treatment is carried out to increase the biodegradability of the effluent and to reduce its toxicity, which lets expect a complete mineralization during the subsequent biological treatment. 
Direct electrochemical oxidation/reduction of recalcitrant pollutants has also been recently reported as a possible pre-treatment before a biological mineralization. This method consists in an electrochemical reaction on electroactive functional groups that are susceptible to be responsible of the non-biodegradability of the molecule. Thus, mild degradation of recalcitrant electroactive compounds, reducing their toxicity and enhancing their biodegradability can be achieved without the intervention of highly reactive hydroxyl radicals. The effectiveness of the method has been demonstrated for recalcitrant molecules such as phosmet an organophosphorous insecticide [31-32], a chlorinated phenoxy herbicide, 2, 4-dichlorophenoxyacetic acid [33-34], and an antibiotic, tetracycline [35].

Sulfamethazine (STM) (Fig. 1) is an antibiotic that belongs to the pharmaceutically important group of heterocyclic sulfonamides. It is widely used in medicine and veterinary practice as antibacterial drug in pharmaceutical preparations [26]. Its structure is presented in Figure 1. Degradation of sulfamethazine has been studied through different methods. However, all studies deals with Advanced Oxidation Processes, such as photo-Fenton [25] and photocatalysis with $\mathrm{TiO}_{2}$ and $\mathrm{ZnO}$ as catalysts [26]. A recent study has also shown the efficacy of an integrated process coupling electro-fenton and biological treatment for sulfamethazine removal [27].

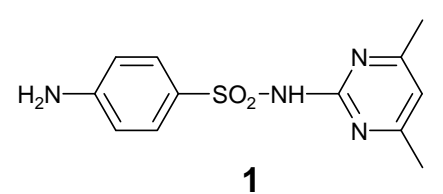

1

Fig.1. Chemical structure of sulfamethazine

In this work, the feasibility of coupling a direct electrochemical process with a biological treatment to degrade sulfamethazine was examined. The pre-treatment was achieved in an electrochemical flow cell using a graphite felt electrode of high specific surface. Such an electrochemical system presents the advantages to transform large amounts of products in a relatively short reaction time. It can be easily automated and therefore adaptable to industry. The influence of various parameters, such as the flow rate and the applied potential, on the degradation of the molecule and the biodegradability of by-products was investigated. These latter were also identified by UPLC-MS/MS. 


\section{Materials and methods}

\subsection{Chemicals and materials}

Sulfamethazine (purity $99 \%$ ) was obtained from Alfa Aesar (Schiltigheim, France). Inert supporting electrolyte $\mathrm{Na}_{2} \mathrm{SO}_{4}$ (purity $99 \%$ ) was purchased from Carlo Erba Reactif-SDS Acetonitrile (purity 99.9\%) was HPLC grade obtained from Sigma-Aldrich. Graphite felt (RVG 4000) was supplied by Mersen (France). Its specific area measured by the BET method, its volume density and its carbon content were $0.7 \mathrm{~m}^{2} \mathrm{~g}^{-1}, 0.088 \mathrm{~g} \mathrm{~cm}^{-3}$ and $99.9 \%$, respectively.

\subsection{Materials for the electrochemical pre-treatment}

Electrochemical pre-treatment, in continuous system, was performed in a home-made flow cell [33]. Two interconnected PAPYEX carbon papers supplied by Mersen (France) were used as counter-electrodes $(85 \mathrm{~mm} \times 85 \mathrm{~mm})$ and the compartments were separated by cationic exchange membranes (Ionac 3470 - Lanxess SAS, Courbevoie, France). The reference electrode (Saturated Calomel Electrode - SCE) was positioned in the middle of the graphite felt (48 $\mathrm{mm}$ diameter and $12 \mathrm{~mm}$ width) and the potential control was performed using a potentiostat. To ensure a good homogeneity of the potential distribution in the three dimensional working electrode, the felt was located between the two counter-electrodes [36]. The cell was thoroughly rinsed with distilled water before and after each experiment. The solution $\left(50 \mathrm{mg} \mathrm{L}^{-1}\right.$ sulfamethazine in $\left.0.1 \mathrm{M} \mathrm{Na}_{2} \mathrm{SO}_{4}\right)$ percolated the porous electrode at various flow rates monitored by a Gilson minipuls 2 peristaltic pump (Middleton, WI, USA).

\subsection{Analytical procedure}

\subsubsection{Electrochemical analysis}

Electrochemical analysis of sulfamethazine and electrolyzed solutions were performed using a conventional three-electrode cell with a glassy carbon electrode $\left(7 \mathrm{~mm}^{2}\right)$ as the working electrode and a platinum wire as the counter electrode. All potentials were measured with respect to a saturated calomel electrode (SCE) located near the working electrode. Experiments were performed at room temperature under nitrogen atmosphere to avoid dissolved oxygen. Voltammograms were obtained by cyclic voltammetry using a versaSTAT3 AMETEK Model (Princeton Applied Research) potentiostat/galvanostat. Before each 
experiment, the glassy carbon electrode was thoroughly polished with Struers waterproof silicon carbide paper.

\subsubsection{High Performance Liquid Chromatography (HPLC)}

The residual sulfamethazine concentration was determined by HPLC using a Waters 996 system equipped with waters 996 PDA (Photodiode Array Detector) and Waters 600 LCD Pump. The separation was achieved on a Waters C-18 (5 $\mu \mathrm{m} ; 4.6 \times 250 \mathrm{~mm})$ reversed-phase and the mobile phase consisted of a mixture of acetonitrile/ultra-pure water $(35 / 65, \mathrm{v} / \mathrm{v})$ delivered at a flow rate of $1 \mathrm{~mL} / \mathrm{min}$. Detection of sulfamethazine was carried out at $268 \mathrm{~nm}$ and the retention time was approximately $5 \mathrm{~min}$.

\subsubsection{Liquid chromatography-mass spectrometry (UPLC-MS/MS)}

\section{Ultra-pressure liquid chromatography}

The devices used are detailed in a previous work [32]. The analytes were separated by a Waters Acquity UPLC system (Waters Corporation, Milford, MA, USA) consisting of an Acquity UPLC binary solvent manager, an Acquity UPLC sample manager and an Acquity UPLC column heater equipped with a Waters Acquity UPLC BEH C18 column $(2.1 \mathrm{~mm} \times$ $100 \mathrm{~mm}, 1.7 \mu \mathrm{m}$ particle size) (Milford, MA, USA) ) maintained at $45{ }^{\circ} \mathrm{C}$. Isocratic LC elution was performed with $0.1 \%$ formic acid in acetonitrile as mobile phase $\mathrm{A}$ and an ultrapure water 9.5:0.5 acetonitrile (v/v) mix, with added $0.1 \%(\mathrm{v} / \mathrm{v})$ of formic acid as mobile phase B. Separation of the analytes on the column was performed with a mobile phase consisting of a mixture of phase A/phase B $(5 / 95, \mathrm{v} / \mathrm{v})$ delivered at a flow rate of $0.4 \mathrm{~mL}$ $\min ^{-1}$.

\section{Tandem mass spectrometry}

The separated compounds were detected with a Waters Micromass Quattro Premier (Waters Corporation, Manchester, UK) triple quadrupole mass spectrometer. It was operated with an electrospray source in positive ionization mode with a cone potential of $40 \mathrm{~V}$. The ionization source conditions were: capillary voltage of $3.0 \mathrm{kV}$, source temperature of $120{ }^{\circ} \mathrm{C}$ and desolvation temperature of $350{ }^{\circ} \mathrm{C}$. The cone and desolvation gas flows were $50 \mathrm{~L} \mathrm{~h}^{-1}$ and 750 $\mathrm{L} \mathrm{h}^{-1}$, respectively; they were obtained from an in-house nitrogen source. High-purity argon (99.99\%, Air Liquid, Paris, France) was used as collision gas and was regulated at $0.1 \mathrm{~mL}$ 
$\min ^{-1}$. Analyses were performed in full scan and daughter scan modes. Spectra were acquired between 50 and $300 \mathrm{~m} / \mathrm{z}$ and the data were treated with Micromass MassLynx 4.1 software.

\subsubsection{Total Organic Carbon (TOC) measurements}

The solutions were filtered on Sartorius Stedim Minisart $0.40 \mu \mathrm{m}$ GF prefilters (Goettingen, Germany). TOC was measured by means of a TOC- $\mathrm{V}_{\mathrm{CPH} / \mathrm{CPN}}$ Total Organic Analyzer Schimadzu. Organic carbon compounds were combusted and converted to $\mathrm{CO}_{2}$, which was detected and measured by a non-dispersive infrared detector (NDIR). Reproducible TOC values were always obtained using the standard NPOC (Non-Purgeable Organic Carbon) method. For each sample, each measurement was triplicated.

\subsubsection{Chemical Oxygen Demand (COD) measurements}

Chemical Oxygen Demand was measured by means of a Test Nanocolor ${ }^{\circledR}$ CSB 160 and 300 from Macherey-Nagel (Düren, Germany). The amount of oxygen required for the oxidation of the organic and mineral matter at $164{ }^{\circ} \mathrm{C}$ for 30 min was quantified after oxidation with $\mathrm{K}_{2} \mathrm{Cr}_{2} \mathrm{O}_{7}$ at acidic $\mathrm{pH}$ and heating.

\subsubsection{Biological Oxygen Demand $\left(\mathrm{BOD}_{5}\right)$ measurements}

Biodegradability was deduced from $\mathrm{BOD}_{5}$ measurements, carried out in Oxitop IS6 (WTW, Alès, France). Activated sludge provided by a wastewater treatment plant (Rennes Beaurade, Bretagne, France) was used to inoculate the flasks and the initial microbial concentration was $0.5 \mathrm{~g} \mathrm{~L}^{-1}$.

The following mineral basis was used for all experiments $\left(\mathrm{g} \mathrm{L}^{-1}\right): \mathrm{MgSO}_{4} .7 \mathrm{H}_{2} \mathrm{O}, 22.5 ; \mathrm{CaCl}_{2}$, 27.5; $\mathrm{FeCl}_{3}, 0.15 ; \mathrm{NH}_{4} \mathrm{Cl}, 2.0 ; \mathrm{Na}_{2} \mathrm{HPO}_{4}, 6.80 ; \mathrm{KH}_{2} \mathrm{PO}_{4}, 2.80$. The $\mathrm{BOD}_{5}$ value was initially estimated based on the experimental COD value $\mathrm{BOD}_{5}=\mathrm{COD} / 1.46$. The range of expected $\mathrm{BOD}_{5}$ values was then deduced giving rise to the volumes of sample and activated sludge solution and of nitrification inhibitor $\left(10 \mathrm{mg} \mathrm{L}^{-1}\right.$ solution of $N$-Allylthiourea) which have to be added in the shake flask of the Oxitop apparatus. A similar protocol was applied for the control flask except that it was replaced by a solution of easily biodegradable compounds, namely glutamic acid $\left(150 \mathrm{mg} \mathrm{L}^{-1}\right)$ and glucose $\left(150 \mathrm{mg} \mathrm{L}^{-1}\right)$. Before use, $\mathrm{KOH}$ was added to achieve neutral $\mathrm{pH}(7.0 \pm 0.2)$. Similar protocol was also considered for the blank solution, for which the sample was replaced by water to deduce the biological oxygen demand corresponding to the endogenous respiration. 


\section{Results and discussion}

\subsection{Electrochemical behavior of sulfamethazine}

The good solubility of sulfamethazine in water was advantageously used to determine the electroactivity of sulfamethazine. Thus, its electrochemical behavior $\left(50 \mathrm{mg} \mathrm{L}^{-1}\right)$ was studied in neutral salts $\left(\mathrm{Na}_{2} \mathrm{SO}_{4} 0.1 \mathrm{~mol} \mathrm{~L}^{-1}\right)$ by cyclic voltammetry on a glassy carbon electrode. The analytical study was performed at neutral $\mathrm{pH}$ in view of a direct use of the electrolyzed solution as growth medium for subsequent biodegradation experiments.

The voltammogram obtained during the anodic sweep showed an irreversible wave at 1V/SCE (Fig. 2). By contrast, during the cathodic sweep in the same conditions, the voltammogram did not show any signal corresponding to the electrochemical reduction of sulfamethazine. This behavior was in agreement with the profiles reported for sulfamethazine in the literature [27].

These results proved the electroactive behavior of sulfamethazine in neutral medium and allowed to conclude on the feasibility of an electrochemical pre-treatment in oxidation.

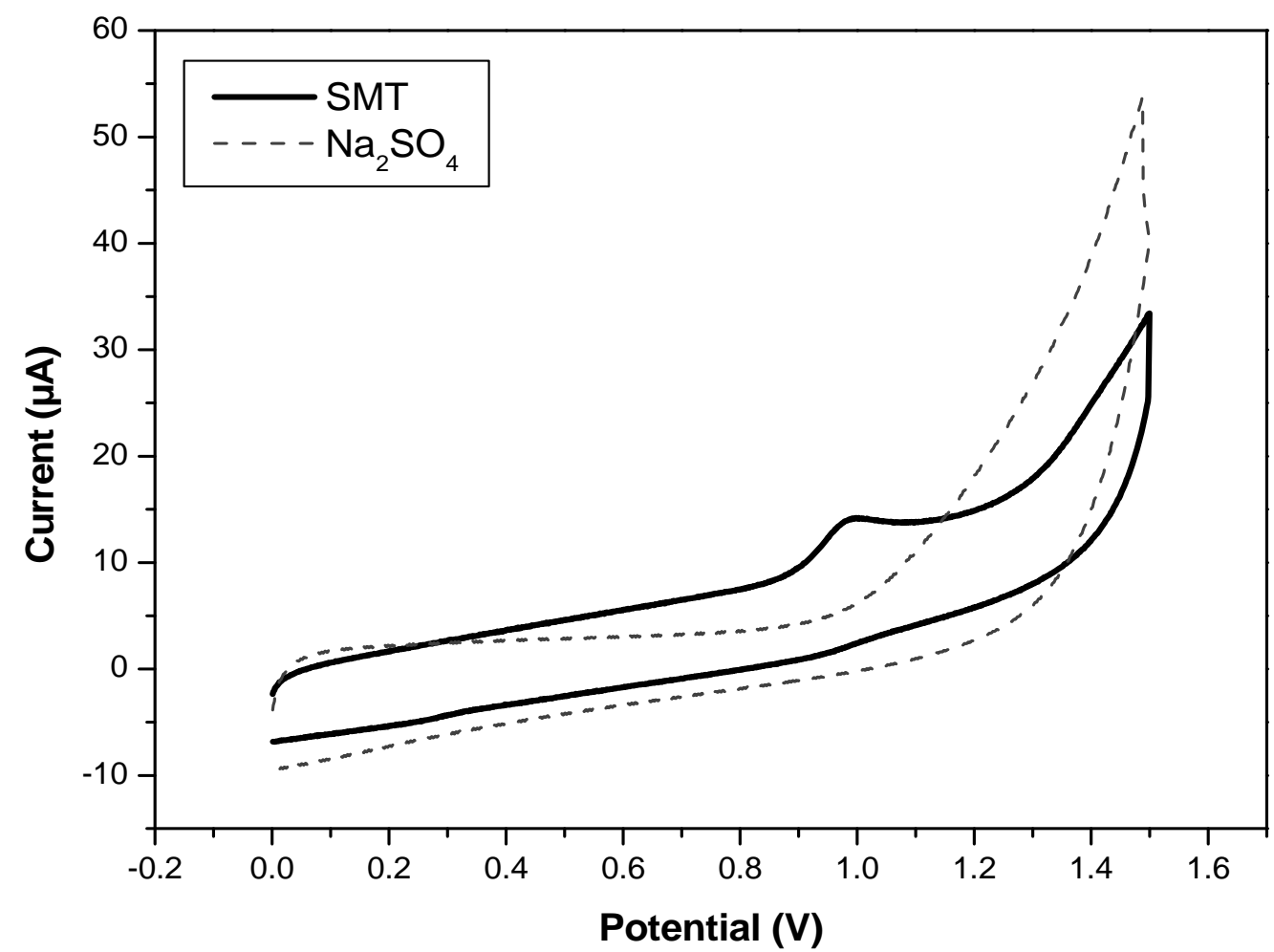

Fig.2. Cyclic voltammetry of a sulfamethazine (SMT) solution $\left(50 \mathrm{mg} \mathrm{L}^{-1}\right)$ during anodic sweep. 
Voltammograms were recorded at $100 \mathrm{mV} \mathrm{s}^{-1}$ in $\mathrm{Na}_{2} \mathrm{SO}_{4}(0.1 \mathrm{M})$ on a glassy carbon electrode, under nitrogen atmosphere

\subsection{Sulfamethazine electrolysis}

The sulfamethazine solution $\left(50 \mathrm{mg} \mathrm{L}^{-1}\right)$ was oxidized at $1 \mathrm{~V} / \mathrm{SCE}$ at various flow rates (from 1 to $4 \mathrm{~mL} \mathrm{~min}^{-1}$ ) in the electrochemical flow cell.

After a single pass through the flow cell, the voltammogram of the electrolyzed solution showed the disappearance of the wave at $1 \mathrm{~V} / \mathrm{SCE}$ confirming the oxidation of sulfamethazine at this potential (Fig. 3a). 

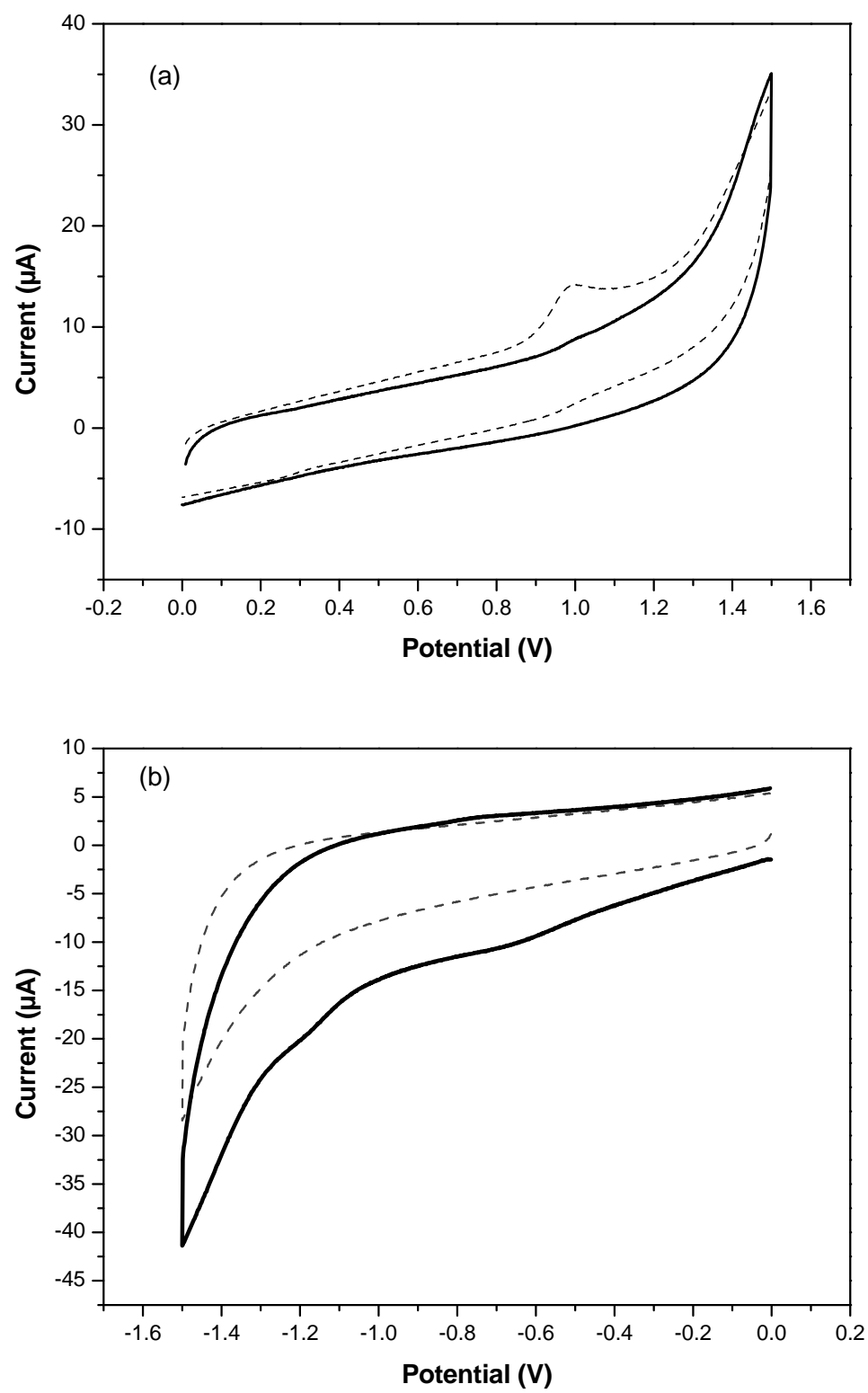

Fig.3. Cyclic voltammetry of a sulfamethazine solution $\left(50 \mathrm{mg} \mathrm{L}^{-1}\right)$ before $(--)$ and after $(-)$ electrolysis in the flow cell at $1 \mathrm{~V} / \mathrm{SCE}\left(1 \mathrm{~mL} \mathrm{~min}^{-1}\right)$. Voltammograms were recorded at $100 \mathrm{mV} \mathrm{s}^{-1}$ in $\mathrm{Na}_{2} \mathrm{SO}_{4}(0.1 \mathrm{M})$ on a glassy carbon electrode during anodic a) and cathodic b) sweep, under nitrogen atmosphere

Advantageously, after pre-treatment, the solution exhibited a new electrochemical signal corresponding to a reduction, when compared with the same analysis performed before electrolysis (Fig. 3b). It is an interesting result because if by-products obtained after the anodic treatment are not biodegradable, a second electrolysis in reduction could be tested. 
Since cyclic voltammetry analysis does not allow the detection of low concentrations, the residual sulfamethazine concentrations were estimated by HPLC for all studied flow rates (Table 1). Above $3 \mathrm{~mL} \mathrm{~min}^{-1}$, the preferential routes of sulfamethazine into the carbon felt did not allow a good electron transfer and high conversion yields. Interestingly, there was no significant impact of the flow rate in the range 1-3 $\mathrm{mL} \mathrm{min}^{-1}$; conversion yields higher than $90 \%$ were obtained with only a single pass through the flow cell. $3 \mathrm{~mL} \mathrm{~min}^{-1}$ can be therefore considered, reducing the electrolysis time.

This result confirms the feasibility of the electrochemical pre-treatment and suggests that until $3 \mathrm{~mL} \mathrm{~min}^{-1}$ flow rate, the recycling of the electrolyzed solution through the electrochemical flow-cell was probably not necessary.

Table 1 : Degradation yield of sulfamethazine after electrochemical pre-treatment, in oxidation $(1 \mathrm{~V} / \mathrm{SCE})$ at different flow rates

\begin{tabular}{lcccccccc}
\hline Flow rate $\quad\left(\mathbf{m L ~} \mathbf{~ m i n}^{-1}\right)$ & 1 & 1.5 & 2 & 2.5 & 3 & 3.5 & 4 \\
\hline Conversion yield (\%) & 94 & 93 & 92 & 91 & 92 & 75 & 76 \\
\hline
\end{tabular}

\subsection{Mineralization of sulfamethazine}

The mineralization trend of sulfamethazine on a carbon felt electrode was examined at different flow rates (Fig. 4a). Even if HPLC analysis showed that sulfamethazine was almost completely degraded after oxidation (1 V/SCE), the mineralization level remained low since the obtained TOC values were not far from that of untreated sulfamethazine. The mineralization yield did not exceed $20 \%$.

This result is promising in view of the combined process, since the objective of the electrochemical pre-treatment is only an increase of the biodegradability of the solution; the purpose is to degrade the target compound to obtain by-products which were expected to be biologically assimilable by microorganisms from activated sludge. The mineralization of the effluent is expected to be achieved during a subsequent biological treatment and hence significant residual organic carbon is necessary for microbial culture. 

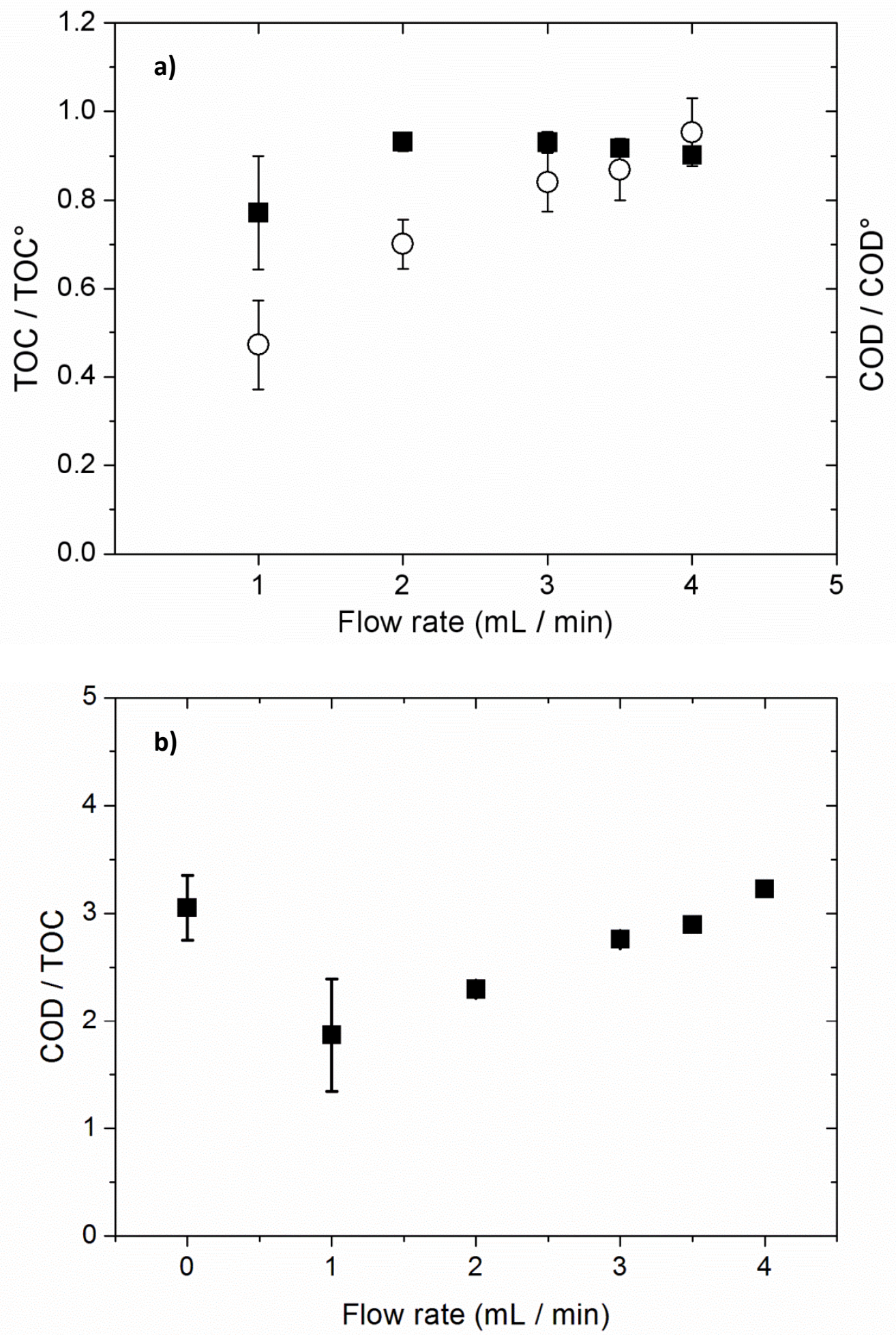

Fig.4 a) Evolution of a) $\mathrm{TOC} / \mathrm{TOC}_{0}$ ratio ( $\bullet$ ), $\mathrm{COD} / \mathrm{COD}_{0}$ ratio (o) and b) $\mathrm{COD} / \mathrm{TOC}$ ratio after electrochemical pre-treatment, in oxidation $(1 \mathrm{~V} / \mathrm{SCE})$ at different flow rates. Initial concentration of sulfamethazine: $50 \mathrm{ppm}$. Error bars are based on 4 reproducibility measurements for $\mathrm{TOC}^{\circ}$ and $\mathrm{COD}^{\circ}$ and 2-3 for TOC and COD for low flow rates. 


\subsection{COD measurements}

The evolution of the chemical oxygen demand showed a decrease after treatment (Fig. 4a). This reduction was significant for solutions percolated at 1 and $2 \mathrm{~mL} \mathrm{~min}^{-1}$ (54\% and $31.5 \%$ COD decrease, respectively). Consequently, low flow rates appeared advantageous to insure a significant COD decrease, while keeping low mineralization yields.

This result confirmed the sulfamethazine oxidation and therefore a modification of its chemical structure, which let expect a decrease of its toxicity, and hence can be in favor of a subsequent biological treatment.

The relevance of the coupling of an electrochemical pre-treatment and a biological process can be also estimated from the examination of the evolution of the COD/TOC ratio, displayed in Fig. 4b. A favorable trend is a decrease of this ratio [19], which was experimentally observed after the electrochemical pre-treatment in oxidation $(1 \mathrm{~V} / \mathrm{SCE})$. Indeed, 59\% and $25 \%$ decrease of COD/TOC were observed for solutions percolated at 1 and $2 \mathrm{~mL} \mathrm{~min}^{-1}$, indicating a significant change in the compound structure.

\subsection{Biodegradability of sulfamethazine}

The biodegradability of a compound can be estimated through the $\mathrm{BOD}_{5}$ on $\mathrm{COD}$ ratio; an effluent is considered as biodegradable for values beyond 0.4 [37-38].

Biodegradability was assessed in the most favorable case, namely the flow rate leading to the most significant COD/TOC decrease, viz. $1 \mathrm{~mL} \mathrm{~min}^{-1}$; the observed $\mathrm{BOD}_{5} / \mathrm{COD}$ ratio was 0.14 , showing a slight increase of the biodegradability of the sulfamethazine solution (initial ratio: 0.08). This increase may be expected owing to the significant COD decrease observed $(54 \%)$. However, the ratio remained lower than the limit of biodegradability (0.4). This result indicates the lack of biodegradability of the by-products formed after the electrochemical treatment.

3.6. Effect of the oxidation potential on the biodegradability of by-products 
In order to improve biodegradability, $1 \mathrm{~mL} \mathrm{~min}^{-1}$ flow rate was kept but higher oxidation potentials were considered, in the range 1.2-1.6 V/SCE. An improvement of by-products degradation may be expected from higher anodic potential, which may be in favor of an electrolysis pre-treatment. COD/TOC remained lower than the initial value, but if compared to the value found for $1.0 \mathrm{~V} / \mathrm{SCE}$ no further significant decrease was obtained (Fig. 5).

However, and interestingly, biodegradability increased with the applied potential; an augmentation of the $\mathrm{BOD}_{5} / \mathrm{COD}$ ratio from 0.14 to 0.58 was obtained for increasing potentials from 1 to $1.6 \mathrm{~V} / \mathrm{SCE}$ respectively (Table 2), and hence at $1.6 \mathrm{~V} / \mathrm{SCE}$ by-products from sulfamethazine oxidation could be considered as biodegradable $\left(\mathrm{BOD}_{5} / \mathrm{COD}=0.58>0.4\right)$. $\mathrm{A}$ biological treatment can be therefore envisaged after the electrochemical pre-treatment.

\section{Table 2}

Impact of the applied potential on the biodegradability of the electrolyzed solutions. Electrolysis conditions: $[\mathrm{SMT}]_{0}=50 \mathrm{mg} \mathrm{L}^{-1}, 1 \mathrm{~mL} \mathrm{\operatorname {min } ^ { - 1 }}$

\begin{tabular}{cccc}
\hline Applied potential (V) & BOD $_{\mathbf{5}}\left(\mathbf{m g ~ O}_{\mathbf{2}} \mathbf{L}^{-\mathbf{1}}\right)^{\mathbf{a}}$ & $\mathbf{C O D ~}\left(\mathbf{m g ~ O}_{\mathbf{2}} \mathbf{L}^{-\mathbf{1}}\right)^{\mathbf{a}}$ & $\mathbf{B O D}_{5} / \mathbf{C O D}^{\mathbf{a}}$ \\
\hline 0 & $6 \pm 0$ & $70 \pm 8$ & $0.08 \pm 0.01$ \\
1 & 4 & $28 \pm 0.7$ & $0.14 \pm 0.00$ \\
1.2 & $9 \pm 5$ & $53 \pm 6$ & $0.17 \pm 0.11$ \\
1.4 & $9 \pm 5$ & $56 \pm 17$ & $0.16 \pm 0.14$ \\
1.6 & $29 \pm 5$ & $50 \pm 10$ & $0.58 \pm 0.21$ \\
\hline
\end{tabular}

${ }^{\mathrm{a}}$ Uncertainties are based on two reproducibility measurements 


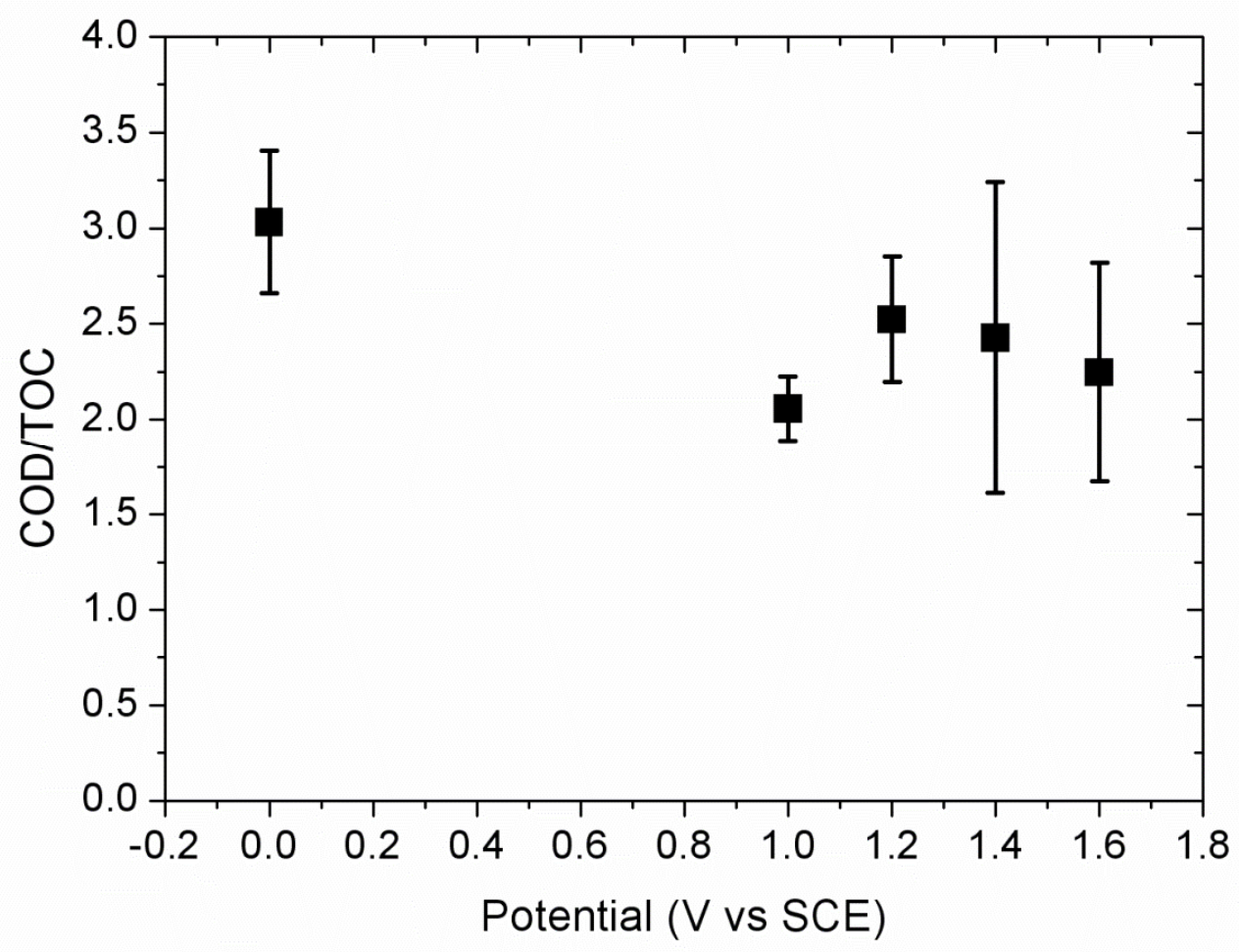

Fig.5. Effect of the oxidation potential on the COD/TOC ratio. Initial concentration of sulfamethazine: $50 \mathrm{ppm}$. Error bars are based on two reproducibility measurements.

\subsection{Degradation by-products analysis}

Sulfamethazine was oxidized in a flow electrochemical cell at $1 \mathrm{~mL} \mathrm{~min}^{-1}$. To allow the determination of by-products that are in very low concentration in the electrolyzed solution, the oxidation was performed at 1.2 V/SCE with a solution of $100 \mathrm{ppm}$ of sulfamethazine in $0.1 \mathrm{M} \mathrm{Na}_{2} \mathrm{SO}_{4}$. For comparison, a blank was performed in the same conditions but without sulfamethazine.

After electrolysis, the sulfamethazine solution was analyzed by UPLC-MS/MS. Comparison with the blank showed the presence of 7 chromatographic peaks corresponding to byproducts. However, since the same molecular mass was obtained for different chromatographic peaks, this information was not sufficient to identify all by-products.

To get insight into the structure of each compound, spectra acquisition of these compounds have been made with collision energy of $25 \mathrm{eV}$, giving rise to fragmentation peaks. The values obtained for sulfamethazine and by-products are given in Table 3.

Table 3: UPLC-MS/MS analysis of by-products 


\begin{tabular}{|c|c|c|c|c|c|c|}
\hline \multicolumn{3}{|c|}{ Electrolyzed solution } & \multicolumn{4}{|c|}{ Standards } \\
\hline Retention time & $\mathrm{MH}^{+}$ & Ion fragment & Products & Retention time & $\mathrm{MH}^{+}$ & Fragment ion \\
\hline \multirow{3}{*}{0.7} & 125 & 67 & 2 & 0.6 & 125 & 66.7 \\
\hline & & 81.5 & & & & 81.8 \\
\hline & & 107.8 & & & & 106.9 \\
\hline \multirow[t]{3}{*}{0.7} & 124 & 66.8 & 3 & 0.7 & 124 & 106.7 \\
\hline & & 107.1 & & & & 81.7 \\
\hline & & 82 & & & & 66.2 \\
\hline \multirow[t]{5}{*}{0.79} & 215.2 & 172.8 & & & & \\
\hline & & 107.3 & & & & \\
\hline & & 132.8 & & & & \\
\hline & & 157.6 & & & & \\
\hline & & 197.9 & & & & \\
\hline \multirow{5}{*}{$\overline{0.83}$} & 216.1 & 133.8 & & & & \\
\hline & & 174 & & & & \\
\hline & & 82.1 & & & & \\
\hline & & 126.8 & & & & \\
\hline & & 159.1 & & & & \\
\hline \multirow[t]{3}{*}{0.85} & 214.1 & 107.4 & & & & \\
\hline & & 185.8 & & & & \\
\hline & & 198.3 & & & & \\
\hline \multirow[t]{4}{*}{1.18} & 215.2 & 107.8 & 4 & 1.1 & 215.27 & 198 \\
\hline & & & & & & 107.7 \\
\hline & & 198.1 & & & & 82 \\
\hline & & 158.1 & & & & \\
\hline \multirow[t]{5}{*}{1.59} & 216.1 & 82 & 5 & 1.56 & 216 & 106.8 \\
\hline & & 106.5 & & & & 108.7 \\
\hline & & 158.8 & & & & 81.8 \\
\hline & & 198.5 & & & & 198.5 \\
\hline & & 108.7 & & & & 158.7 \\
\hline \multirow[t]{5}{*}{2.04} & 279.2 & 91.8 & 1 & 2.04 & 279.2 & 91.9 \\
\hline & & 123.9 & & & & 107.8 \\
\hline & & 107.8 & & & & 123.9 \\
\hline & & 185.5 & & & & 185.9 \\
\hline & & 155.8 & & & & 155.8 \\
\hline
\end{tabular}

Retention times and mass spectra were compared with standard compounds (Table 3 and Fig. 6).
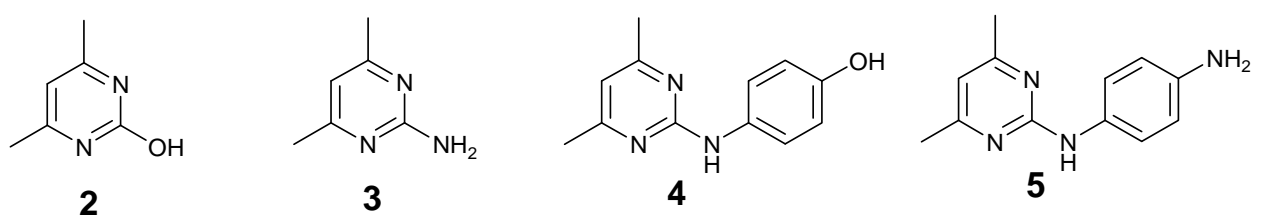

Fig. 6: Structure of the identified by-products 
The remaining sulfamethazine was observed at $2.04 \mathrm{~min}$ and four by-products were identified among the other 7 peaks obtained by UPLC-MS/MS. The slight difference observed between the mass spectra of the first peak $(0.7 \mathrm{~min})$ and the standard 2 can be explained by the high background noise. This compound was probably present but at a very low concentration.

It has been reported that the electrochemical oxidation of sulfamethazine takes place on the amino group and led to the formation of azo and nitroso species [39]. Such compounds have not been observed after electrolysis, neither by cyclic voltammetry nor by UPLC-MS/MS. According to the by-products identified by UPLC-MS/MS, the key step responsible of the degradation of sulfamethazine was the cleavage of the sulfonamide. It has been reported that the oxidation of sulfadiazine, a sulfonamide antibiotic, on glassy carbon and boron-doped diamond electrodes led to the formation of 3 by cleavage of the sulfonamide group [40]. The authors have proposed a mechanism involving the formation of an anilinium cation (Fig. 7).

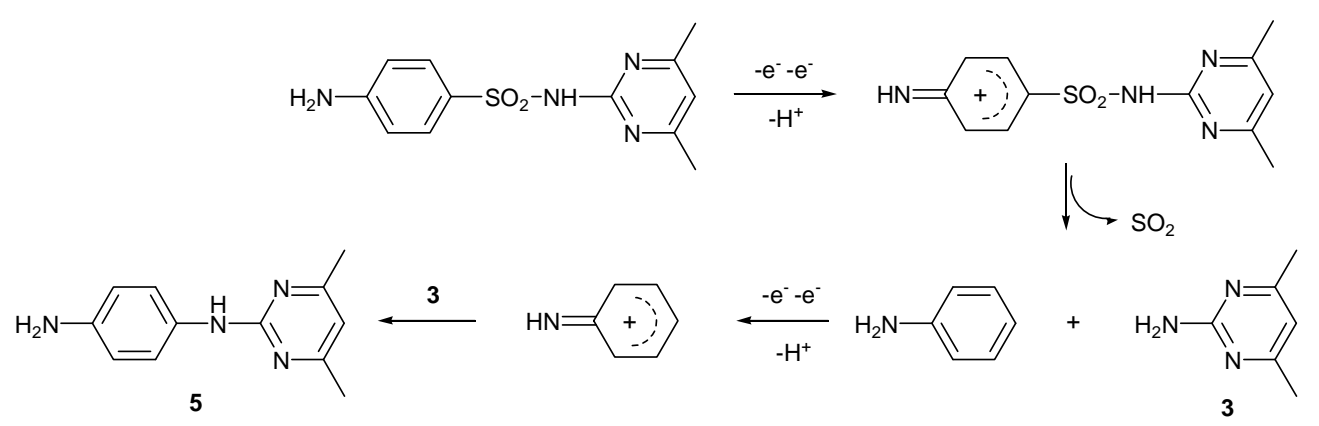

Figure $7:$ mechanism proposed for the formation of identified by-products [40]

The presence of by-products 3 and 5 could be explained, according to Fig. 7, by the formation of this reactive intermediate. Further reactions on $\mathbf{3}$ and $\mathbf{5}$ probably gave rise to by-products $\mathbf{2}$ and 4 , respectively.

To check the influence of the applied potential on the nature of by-products formed after electrolysis, a solution of $50 \mathrm{ppm}$ of sulfamethazine in $0.1 \mathrm{M} \mathrm{Na}_{2} \mathrm{SO}_{4}$ was oxidized at 1.2 and

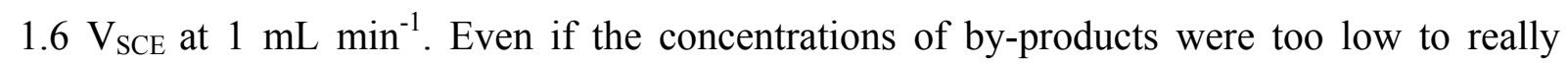
quantify them, an evolution of the composition of the electrolyzed solution was clearly observed. When a potential of $1.6 \mathrm{~V} / \mathrm{SCE}$ was applied, the peak corresponding to the unidentified compound of mass 214.1 increased, whereas compounds $\mathbf{3}$ and $\mathbf{5}$ were observed in lower amounts and no peak corresponding to $\mathbf{2}$ was detected. The compound $\mathbf{4}$ seemed to remain in the same amount. These results show that the identified intermediates $\mathbf{3}$ and $\mathbf{5}$ underwent further oxidation at $1.6 \mathrm{~V} / \mathrm{SCE}$, giving rise to other by-products. The decrease of these intermediate compounds is probably at the origin of the improvement of the biodegradability of the solution. 


\section{Conclusion}

This study demonstrated the efficiency of the electrochemical process as a pre-treatment method for enhancing the biodegradability of sulfamethazine. An analytical study was carried out showing the electroactivity of sulfamethazine in oxidation $(1 \mathrm{~V} / \mathrm{SCE})$, which allows to envisage the coupling between an electrochemical process and a biological treatment. Sulfamethazine was electrolyzed in an electrochemical flow cell using a graphite felt electrode. After a single pass through the cell, the analysis of the electrolyzed solution showed a high degradation yield while mineralization remained limited.

The influence of different parameters such as the flow rate and the applied potential on the degradation of the molecule and the biodegradability of by-products was examined. It was found that the biodegradability increased with the oxidation potential, until values exceeding the threshold limit (0.4). Indeed, the $\mathrm{BOD}_{5} / \mathrm{COD}$ ratio increased from 0.08 to 0.58 for increasing potentials from 1 to $1.6 \mathrm{~V} / \mathrm{SCE}$. To confirm these promising results, a biological treatment should be subsequently carried out to confirm the biodegradability improvement after pre-treatment.

\section{References}

[1] T. Heberer, Toxicol. Lett. 131 (2002) 5-17.

[2 ] K. Kummerer, Chemosphere 75 (2009) 417- 434.

[3] T. Heberer, J. Hydrol. 266 (2006) 175- 189.

[4] D. Kolpin, E. Furlong, M. Meyer, E. M. Thurman, S. Zaugg, L. Barber, H. Buxton, Environ. Sci. Technol. 36 (2002) 1202-1211.

[5] V. L. Cunningham, S. P. Binks, M. J. Olson, Regul. Toxicol. Pharm. 53 (2009) 39-45.

[6] E. R. Cooper, T. C. Siewicki, K. Phillips, Sci. Total Environ. 398 (2008) 26-33.

[7] O. V. Enick, M. M. Moore, Environ. Impact Ass. Rev. 27 (2007) 707-729.

[8] J. P. Bound, N. Voulvoulis, Chemosphere 56 (2004) 1143-1155.

[9] J. P. Bound, N. Voulvoulis, Water Research 40 (2006) 2885-2892.

[10] F. Saravia, F. H. Frimmel, Desalination 224 (2008) 168-171. 
[11] A. Göbel, C. S. McArdell, A. Joss, H. Siegrist, W. Giger, Sci. Total Environ. 372 (2007) $361-371$.

[12] T. X. Bui, H. Choi, J. Hazard. Mater. 168 (2009) 602-608.

[13] I. Braschi, S. Blasioli, L. Gigli, C. E. Gessa, A. Alberti, A. Martucci, J. Hazard. Mater. 178 (2010) 218-225.

[14] S. A. Snyder, S. Adham, A. M. Redding, F. S. Cannon, J. DeCarolis, J. Oppenheimer, E. C. Wert, Y. Yoon, Desalination 202 (2007) 156-181.

[15] A. J. Watkinson, E. J. Murby, S. D. Costanzo, Water Research 18 (2007) 4164-4176.

[16] Z. P. Xing, D. Z. Sun, J. Hazard. Mater. 168 (2009) 1264-1268.

[17] S. Suarez, J. M. Lema, F. Omil, Bioresource Technol. 100 (2009) 2138-2146.

[18] F. Fourcade, M. Delawarde, L. Guihard, S. Nicolas, A. Amrane, Water Air Soil. Pollut. 224 (2012) 1385-1396.

[19] S. Yahiat, F. Fourcade, S. Brosillon, A. Amrane, Desalination 281(2011) 61-67.

[20] A. Dirany, I. Sirés, N. Oturan, A. Ozcan, M. A. Oturan, Environ. Sci. Technol. 7 (2012) 4074- 4082.

[21] S. Hammami, N. Oturan, N. Bellakhal, M. Dachraoui, M. A. Oturan, J. Electroanal. Chem, 610 (2007) 75-84.

[22] M. M. Huber, S. Canonica, G. Y. Park, U. Von Gunten, Environ. Sci. Technol. 37 (2003) $16-24$.

[23] A. Dirany, I. Sires, N. Oturan, M. A. Oturan, Chemosphere 81 (2010) 594-602.

[24] E. Brillas, I. Sirès, C. Arias, P. L. Cabot, F. Contellas, R. M. Rodriguez, J. A. Garrido, Chemosphere 58 (2005) 399-406.

[25] M. Perez-Moya, M. Graells, G. Castells, J. Amigo, E. Ortega, G. Buhigas, L. M. Pérez, H. D. Mansilla, Water Research 44 (2010) 2533-2540.

[26] S. Kaniou, K. Pitarakis, I. Barlagianni, I. Poulios, Chemosphere 60 (2005) 372-380.

[27] D. Mansour, F. Fourcade, N. Bellakhal, M. Dachraoui, D. Hauchard, A. Amrane, Water Air Soil Poll. 223 (2012) 2023-2034.

[28] B. Lodha, S. Chaudhari, J. Hazard. Mater. 148 (2007) 459-466. 
[29] O. Gonzalez, C. Sans, S. Esplugas, J. Hazard. Mater. 146 (2007) 459-464.

[30] S. Yahiat, F. Fourcade, S. Brosillon, A. Amrane, Int. Biodeter. Biodegr. 65 (2011) 9971003 .

[31] N. A. Salles, F. Fourcade, F. Geneste, D. Floner, A. Amrane, J. Hazard. Mater. 181 (2010) 617-623.

[32] M. Assassi, F. Fourcade, F. Geneste, D. Floner, R. Maachi, A. Amrane, Int. J. Environ. Res. 5 (2011) 41-46.

[33] J. M. Fontmorin, S. Huguet, F. Fourcade, F. Geneste, D. Floner, A. Amrane, Chem. Eng. J. 195-196 (2012) 208-217.

[34] J. M. Fontmorin, F. Fourcade, F. Geneste, D. Floner, S. Huguet, A. Amrane, Biochem. Eng. J. 70 (2013) 17-22.

[35] D. Belkheiri, F. Fourcade, F. Geneste, D. Floner, H. Ait-Amar, A. Amrane, Sep. Purif. Technol. 83 (2011) 151-156.

[36] C. Moinet, J. Phys. IV (1994). C1-175- C1-184.

[37] V. Sarria, S. Parra, N. Adler, P. Péringer, N. Benitez, C. Pulgarin, Catal. Today 76 (2002) 301-315.

[38] C. Pulgarin, M. Invernizzi, S. Parra, V. Sarria, R. Polania, P. Péringer, Catal. Today 54 (1999) 341-352.

[39] R. N. Goyal, N. C. Mathur, S. Bhargava, J. Electroanal. Chem. 247 (1988) 229-240.

[40] Th. Hoffmann, D. Hofmann, E. Klumpp, S. Küppers, Anal. Bioanal. Chem. 399 (2011) $1859-1868$. 